УДК 378.09.011.3-051-057.21:004.353

DOI:

Ганна Алєксєєва, кандидат педагогічних наук, доцент кафедри комп'ютерних технологій в управлінні та навчанні й інформатики Бердянського державного педагогічного університету

Лариса Горбатюк, кандидат педагогічних наук, доцент кафедри комп'ютерних технологій в управлінні та навчанні й інформатики Бердянського державного педагогічного університету

Наталія Кравченко, кандидат фізико-математичних наук, доцент кафедри комп'ютерних технологій в управлінні та навчанні й інформатики Бердянського державного педагогічного університету

Ганна Чуприна, кандидат педагогічних наук, доцент кафедри комп'ютерних технологій в управлінні та навчанні й інформатики Бердянського державного педагогічного університету

Олександр Овсянніков, кандидат педагогічних наук, доцент кафедри комп'ютерних технологій в управлінні та навчанні й інформатики Бердянського державного педагогічного університету

\title{
ТЕХНОЛОГІЇ ВІЗУАЛІЗАЦІЇ В ПРОФЕСІЙНІЙ ПІДГОТОВЦІ СПЕЦААЛІСТІВ
}

У статті розглядається проблема використання відеоматеріалів у професійній підготовиі майбутніх інженерів-педагогів, зокрема візуалізацію дидактичних матеріалів упрофесійній підготовці майбутніх фахівців з комп 'ютерних технологій. Доведено, що необхідна зміна парадигми викладання дисциплін комп 'ютерного профілю в контексті візуалізаиї дидактичних матеріалів як основи абстрагування матеріалу. Встановлено, ццо навчання дисииплінам комп'ютерного профілю здійснюється в умовах дуже мінливої предметної області та великої кількості різноманітних методів й інструментальних засобів. Одним з головних принципів навчання студентів стає високий рівень абстрагування навчального матеріалу. Розглянуто класичні методики навчання дисиипліни “Комп'ютерна анімація", які передбачають лекиійно-практичну форму навчання з переважно текстовими дидактичними матеріалами, щуо мають низький рівень абстрагування порівняно з використанням відеоматеріалів.

Ключові слова: вища освіта; професійна підготовка; майбутні інженери-педагоги; інформачійні технології; відеоматеріали.

Jim. 15.

Hanna Alyeksyeyeva, Ph.D.(Pedagogy), Associate Professor of the Informatics and Computer Technologies in Management and Learning Department, Berdyansk State Pedagogical University

Larysa Horbatyuk, Ph.D.(Pedagogy), Associate Professor of the Informatics and Computer Technologies in Management and Learning Department, Berdyansk State Pedagogical University

Nataliya Kravchenko, Ph.D.(Pedagogy), Associate Professor of the Informatics and Computer Technologies in Management and Learning Department, Berdyansk State Pedagogical University

Hanna Chupryna, Ph.D.(Pedagogy), Associate Professor of the Informatics and Computer Technologies in Management and Learning Department, Berdyansk State Pedagogical University Oleksandr Ovsyannikov, Ph.D.(Pedagogy), Associate Professor of the Informatics and Computer Technologies in Management and Learning Department, Berdyansk State Pedagogical University

\section{TECHNOLOGIES OF VISUALIZATION IN PROFESSIONAL TRAINING OF SPECIALISTS}

The research work is devoted to the problem of the use of video materials in the training of future engineerpedagogue, in particular the visualization of teaching materials in the training of future computer technicians. It is proved that the necessary change of the paradigm of teaching the disciplines of the computer profile in the context of visualization of didactic materials as the basis of abstraction of the material. It has been established that the training of disciplines of the computer profile is carried out in a very changing subject area and a large number of different methods and tools. One of the main principles of student learning is the high level of abstraction of learning material. The classical methods of teaching "Computer animation" discipline are considered, which include a lecture-practical form of training with mainly text-based teaching materials that have a low level of abstraction compared with the use of video materials.

It is shown that due to the technical advantages of using video material (speed, maneuverability, efficiency, ability to view and listen to fragments and other multimedia functions; didactic - interactivity of classes (creating 
the presence effect, feeling of authenticity, reality of events, interest, desire to find out and see more)) is carried out improving the quality and efficiency of the educational process.

The didactic bases of the use of video materials in the training of students of computer graphics are determined on the example of the training of future engineer-pedagogues of the faculty of physical and mathematical, computer and technological education of the Berdyansk State Pedagogical University of computer animation.

The organizational and methodical bases of the use of video materials on the example of the study of the discipline "Computer animation" are offered.

It has been established that the use of educational video materials has significant potential and contributes to improving the efficiency of education and guarantees the qualitative training of students.

Keywords: higher education; vocational training; the future engineer educators; an information technology; video materials.

П

Оостановка проблеми та її зв'язок із важливими практичними завданнями. Світова практика розвитку та використання інформаційнокомунікаційних технологій (ІКТ) в системі інженерно-педагогічної освіти демонструє тенденцію до зміни традиційних форм організації освітнього процесу в умовах інформаційного суспільства. Актуальною проблемою сьогодення $\epsilon$ необхідність зміни парадигми викладання дисциплін комп'ютерного профілю. Навчання дисциплінам комп'ютерного профілю здійснюється в умовах дуже мінливої предметної області та великої кількості різноманітних методів й інструментальних засобів. Одним із головних принципів навчання стає високий рівень абстрагування навчального матеріалу. Класичні методики навчання дисципліни “Комп'ютерна анімація" передбачають лекційно-практичну форму навчання 3 переважно текстовими дидактичними матеріалами, які мають низький рівень абстрагування порівняно з використанням відеоматеріалів [6]. 3 огляду на це проблема розробки науково обгрунтованої методики навчання комп'ютерній анімації з використанням відеоматеріалів $\epsilon$ актуальною і вона досліджуватиметься у даній статті.

Аналіз основних досліджень і публікацій. Українськими вченими достатньо висвітлено концептуальні засади процесу інформатизації системи освіти. Питання підготовки майбугніх інженерів-педагогів в умовах інформатизації освіти розкрито в працях Г. Алєксєєвої [1 - 3], [12 - 13], С. Гунько, Ю. Жука, Н. Кравченко [7], А. Майбороди, I. Смирнової, С. Тадіян, А. Трофимова, О. Шиман. Проблема формування професійних навичок інженерів-педагогів досліджувалася в роботах Н. Апатова, А. Ашерова [4], В. Бикова, Л. Бабенко, Л. Білоусової, Л. Горбатюк [4], Ю. Дорошенко, А. Єршова, Б. Житомирського, Н. Лазарева, В. Монахова, А. Піхоти, С. Ракова, В. Хоменко та інших вчених.

Питанню формування компетенцій 3 комп'ютерної графіки присвячені праці А. Глазунова [5], А. Джеджули [6], І. Ніщак [8],
[9], М. Ожга [10], Л. Оршанського, С. Осташук, Н. Полішук, Г. Райковського, І. Савенко, І. Семенова, А. Слободянюк, Ю. Фещук, М. Юсупової, Ю. Яворік та інших вчених. У дисертації А. Джеджули визначено, що особливостями графічної діяльності є: дослідження об'єктів і явищ, абстрагування від їх властивостей; накопичення, зберігання і передача інформації про ці об’єкти та явища в графічній формі [6].

Питанням методики навчання комп'ютерної анімації присвячені статті A. Fedorov [11], S. Park [15], Z. Liu [14]. В роботі Z. Liu проведено дослідження системи підготовки фахівців 3 анімаціїв вищих професійних коледжах і зазначено, що існуючий підхід до ̈̈х підготовки не задовольняе потребам комп'ютерної індустрії, що неминуче тягне за собою реформу професійного навчання фахівців з анімації [14].

Питанням теоретичного обгрунтування, розробки та впровадження в навчальний процес електронних освітніх відеоресурсів присвячені роботи Я. Глинського, В. Лазаренко, Д. Тарасова, Д. Федасюк.

Аналіз цих робіт показав, що незважаючи на високу публікаційну активність 3 питань професійної підготовки студентів і використання відеоматеріалів, які розкривають їх технічну складову і обгрунтовує економічну та педагогічну доцільність використання, недостатньо вивченою $\epsilon$ проблема використання відеоматеріалів в процесі професійної підготовки майбутніх інженерів-педагогів та визначення особливостей і розробки науково обгрунтованої технології навчання комп'ютерної анімації з використанням відеоматеріалів.

Метою статті $\epsilon$ розробка технології навчання комп'ютерній анімації 3 використанням відеоматеріалів у процесі професійної підготовки майбутніх інженерів-педагогів на прикладі навчанні дисципліни “Комп'ютерна анімація" студентів комп”ютерного профілю Бердянського державного педагогічного університету (БДПУ).

Виклад основного матеріалу. В сучасних умовах підвищення суспільних вимог до рівня професіоналізму та конкурентоспроможності 


\section{ТЕХНОЛОГІЇ ВІЗУАЛІЗАЦІЇ В ПРОФЕСІЙНІЙПЦДГОТОВЦІСПЕЦІАЛСТІВ}

майбутніх фахівців виникають питання до сучасної системи вищої освіти. У зв'язку з цим, пошук нових підходів до сучасного освітнього процесу стає актуальним і значущим педагогічним завданням. Одним із альтернативних напрямів його вирішення є змінення підходу до професійної підготовки майбутніх інженерів-педагогів у педагогічному університеті в контексті навчання комп'ютерній анімації [6].

Отже, сучасними світовими тенденціями розвитку інформатизації освіти є: створення єдиного освітнього простору; активне запровадження нових засобів та методів навчання, що орієнтовані на використання інформаційних технологій; синтез засобів та методів традиційного та комп'ютерного навчання; створення системи випереджаючої освіти; виникнення нового напрямку діяльності викладача - розробка інформаційних технологій навчання та програмно-методичних комплексів; зміна змісту діяльності викладача: 3 “репродуктора" знань до розробника нової технології (що з одного боку, підвищує його творчу активність, а з іншого - потребує високого рівня технологічної та методичної підготовки); формування системи безперервного навчання як універсальної форми діяльності, що спрямована на постійний розвиток особистості протягом всього життя [12]. Інформатизація освіти вимагає впровадження у вищу освіту інноваційних за змістом методів, засобів та форм професійної підготовки майбутніх фахівців нової формації, створення потужної інформаційної інфраструктури у закладах вищої освіти 3 розвиненим інформаційно-комп'ютерним навчальним середовищем, впровадження Інтернет-технологій, електронного навчання, комунікаційних мереж (глобальних, національних, локальних). Крім того комп'ютерні технології у навчальному процесі $\epsilon$ складовою частиною педагогічних технологій та вимагають від викладачів розширення професійної підготовки. Зазначено, що комп'ютерні технології дозволяють підвищити якість навчання студентів з врахуванням їх індивідуальних психологічних і фізіологічних особливостей [4].

У сучасному розумінні, інформаційна освітня технологія - це педагогічна технологія, яка використовує спеціальні способи, програмні та технічні засоби (кіно-, відео-, аудіозасоби, комп'ютери, телекомунікаційні мережі) для роботи з інформацією. Узагальнено основні інформаційні технології, що використовуються в процесі викладання, які можна поділити на три категорії: інтерактивні (аудіовізуальні носіі); комп'ютерне навчання (включаючи засоби мультимедіа); засоби телекомунікації (відеоконференції, форуми тощо).

Технології навчання, які грунтуються на комп'ютерних технологіях дають можливість поєднувати процеси вивчення, закріплення i контролю навчального матеріалу 3 індивідуалізацією процесу навчання, зменшуючи фронтальні види робіт і збільшуючи частку індивідуально-групових форм і методів навчання. Це сприятиме підвищенню мотивації до навчання, розвитку креативного мислення, дозволяє економити навчальний час, поєднуючи інтерактивність і мультимедійну наочність, що в кінцевому результаті сприятиме кращому представленню, i, відповідно, кращому засвоєнню інформації [3]. Разом з тим, вони не витісняють традиційні методи і прийоми, але дозволяють наблизити методику навчання до вимог сьогодення. 3 цією метою здійснюється поширення використання в освітній галузі інформаційних освітніх технологій, які базуються на сучасній комп'ютерній базі, інтерактивних методах: комп'ютерні навчальні програми, технічні засоби навчання на базі аудіовідеотехніки, дистанційні засоби навчання, телеконференції тощо.

Наприклад, серед засобів навчання саме мультимедійні займають важливе місце у професійній підготовці майбутніх фахівців. Мультимедійні засоби навчання - це комплекс апаратних і програмних засобів, що дозволяють користувачеві спілкуватися 3 комп'ютером, використовуючи різноманітні, природні для себе середовища: графіку, гіпертексти, звук, анімацію, відео [9]. Вони надають користувачеві такі види інформації: текст; зображення; анімаційні картинки; аудіо коментарі; цифрове відео. Технології, які дозволяють за допомогою комп'ютера інтегрувати, обробляти і водночас відтворювати різноманітні типи сигналів, різні середовища, засоби і способи обміну інформацією, називаються мультимедійними [8].

Розглянемо різноманітні способи застосування засобів мультимедіа в навчальному процесі, серед яких: використання електронних лекторів, тренажерів, підручників, енциклопедій; розробка ситуаційно-рольових та інтелектуальних ігор 3 використанням штучного інтелекту; моделювання процесів і явищ; забезпечення дистанційної форми навчання; проведення інтерактивних освітніх телеконференцій; побудова систем контролю й перевірки знань і умінь студентів (використання контролюючих програм-тестів); створення і підтримка сайтів навчальних закладів; створення презентацій навчального матеріалу; здійснення 


\section{ТЕХНОЛОГІЇ ВІЗУАЛІЗАЦІЇ В ПРОФЕСІЙНІЙ ПІДГОТОВЦІСПЕЦІАЛІСТІВ}

проективної і дослідницької діяльності студентів тощо.

Потрібно підкреслити, що використання засобів мультимедіа, зокрема відеоматеріалів в освітньомупроцесі сприяє: підвищенню мотивації студентів до навчання; реалізації соціальної мети, а саме - інформатизації суспільства; інтенсифікації процесу навчання; розвитку особистості студента; розвитку навичок самостійної роботи 3 навчальним матеріалом; підвищенню ефективності навчання за рахунок його індивідуалізації. Технічними перевагами застосування відеоматеріалів є швидкість, маневреність, оперативність, можливість перегляду i прослуховування фрагментів і інші мультимедійні функції; дидактичними інтерактивність занять (створення ефекту присутності, відчуття автентичності, реальності подій, інтерес, бажання дізнатися і побачити більше).

Аналіз якості й ефективності освітнього процесу 3 використанням відеоматеріалів проведено в дослідженні В. Лазаренко, в якому було використано дані впливу стимулу на електроенцефалографію людини та достовірно встановлено, що фактична присутність лектора в аудиторії значимо підвищує ефективність засвоєння змісту пропонованої відео-лекції. Заняття з використанням відеоматеріалів на лекції може бути двох типів:

1. Коли студенти дивляться навчальне відео від 5 до 15 хв, де спочатку їм розповідається теорія (правило, новий матеріал, можливо, вводиться нова лексика по темі і ін.), а потім наводяться приклади. В даному відеоролику можна привести елементарні завдання, спрямовані на контроль засвоєння побаченого і почутого матеріалу.

2. Коли під час заняття студенти дивляться невеликі відеоролики (фрагменти з мультфільмів, художніх і документальних фільмів, серіалів і науково-пізнавальних програм), які носять пізнавальний характер (новий матеріал по темі, розширення матеріалу, закріплення, повторення). Після перегляду відеоматеріалів студенти виконують найчастіше ряд комунікативних завдань [6].

Якщо ми говоримо про перший тип занять, то даний метод передбачає самостійну роботу викладача на всіх етапах підготовки. Педагогу необхідно мати спеціальну програму для запису відео і вміти нею користуватися. Безумовно, в даний час в інтернеті можна знайти вже готові відеоматеріали з тих чи інших тем, але не завжди вони відповідають конкретній темі заняття. Відеоматеріал може бути даний ширше, ніж потрібно на певному етапі навчання або навпаки, дається лише його мала частина. У даній ситуації викладачу доводиться підлаштовуватися під готову версію відео або створювати новий навчальний матеріал (відео). Тому, знаючи особливості успішності групи, краще за все не шукати відео в інтернеті, а розробляти його. Незважаючи на трудомісткість і час, витрачений на підготовку матеріалів, даний вид роботи на занятті виправдовує себе. Цікава подача матеріалу сприяє зростанню засвоєння матеріалу. Переглядаючи відеоматеріали, студенти активніше залучаються до процесу навчання, а якщо в них ще $€$ інтерактивні завдання, тоді процес сприйняття нової інформації зростає не тільки у зацікавлених в предметі студентів, а й у слабкіших. Ще однією відмінною рисою даного методу можна назвати можливість відпрацювання даного матеріалу студентами самостійно, в разі їх відсутності на занятті: можна переглядати матеріал в зручний час і місце, а в разі ускладнень або виниклих питань, обговорити їх 3 викладачем. Також цей матеріал можуть переглянути ще раз вдома всі бажаючі, закріпивши і відпрацювавши матеріал. В умовах зростання інновацій в сфері інформаційних технологій студенти можуть це зробити навіть за допомогою своїх стільникових телефонів, не кажучи вже про комп'ютери, ноутбуки і планшетах [9].

При проведенні занять другого типу, педагогу потрібно лише підібрати фрагменти відео, які підходять за смисловим змістом заняття i досліджуваного матеріалу, тобто, створювати відео самому не потрібно. Потім педагог підбирає або розробляє самі вправи і завдання, які виконуються студентами до, вчасно і після перегляду відео фрагмента. Вправи можуть бути індивідуальними, з різним ступенем складності, що забезпечує індивідуальний і диференційований підходи в навчанні, груповими, що допомагає розвитку навичок соціалізації серед однолітків і спрямованими до роботи з усією групою, коли змагальний момент підштовхує студентів до більш активної участі на занятті. Використання даного типу заняття мотивує студентів на вивчення матеріалу своїм нестандартним підходом в його подачі, підвищується інтерес студентів до заняття, вони більше запам'ятовують, на занятті відчувається емоційний комфорт.

Використання на лекційних заняттях відеоматеріалів формує вміння студента перетворювати усну та письмову інформацію у візуальну форму, виділяючи при цьому найбільш значущі і істотні елементи [12]. Проведення лекції 


\section{ТЕХНОЛОГІЇ ВІЗУАЛІЗАЦЇ̈ В ПРОФЕСІЙНІЙПІДГОТОВЦІСПЕЦІАЛСТІВ}

зводиться до зв'язного розгорнутого коментування викладачем підготовлених наочних посібників [13].

Таким чином, незважаючи на те, що використання відеоматеріалів це всього лише фрагмент заняття, під час якого студенти отримують ту чи іншу інформацію за допомогою цифрового носія, вчаться іiї сприймати і адекватно застосовувати на практиці, використання відеоматеріалів підвищує інтерес до вивчення предмету і дає можливість якісно підвищити рівень професійної підготовки майбутніх фахівців.

Опишемо більш детально досвід навчання дисципліни “Комп'ютерна анімація” майбутніми інженерами-педагогами Бердянського державного педагогічного університету з використанням технології навчання комп'ютерній анімації 3 використанням відеоматеріалів.

Метою використання відеоматеріалів в професійній підготовці інженерів-педагогів є: підвищення якості навчання за рахунок інтенсифікації навчального процесу, індивідуалізації і диференціації, активізації роботи студентів; реалізація таких педагогічних принципів як науковість i доступність, системність i послідовність, індивідуальний, диференційований, особистісно-орієнтований підхід [5], [10], [12].

Досягнення вищезазначеної мети буде здійснюватися на основі реалізації системи принципів. Всі принципи тісно пов'язані між собою i утворюють єдину систему, покликану забезпечити досягнення поставлених цілей. У той же час можна виділити принципи, які грають провідну роль у використанні відеоматеріалів в професійній підготовці інженерів-педагогів. Слід зазначити, що система принципів допускає включення нових принципів і переосмислення вже існуючих. Детально зупинимося на принципах, найбільш важливих для використання відеоматеріалів в професійній підготовці інженерів-педагогів [14], [15].

Принцип індивідуалізації навчання передбачає, що засвоєння навчального матеріалу, темп оволодіння ним, міцність і свідомість знань залежать не від однієї тільки діяльності викладача, а й від пізнавальних можливостей і здібностей студентів, обумовлених багатьма чинниками, у тому числі особливостями сприйняття, пам'яті, мисленєвої діяльності, фізичним розвитком.

Принцип наочності полягає в комп'ютерній візуалізації навчальної інформації.

Принцип доступності полягає в необхідності відповідності змісту, методів і форм навчання особливостям студентів і рівню їх розвитку. Серед основних положень даного принципу виділяють такі: необхідність збігу темпу повідомлення інформації викладачем і швидкості засвоєння цієі інформації студентами; орієнтація студентів, насамперед, на розуміння досліджуваного матеріалу, а не на запам'ятовування; рух “від простого до складного”, “від близького до далекого”, “від легкого до важкого”, “від відомого до невідомого” тощо.

Принцип надмірності має на увазі завідомо надмірну кількість завдань, які не можуть бути виконані тільки у визначений час. Надмірність $\epsilon$ необхідною умовою організації навчальної діяльності в аудиторії, що має різний рівень підготовленості з предмету: залежно від рівня підготовленості студента викладач має можливість запропонувати йому завдання того чи іншого рівня складності. Крім того, надмірність забезпечує викладачу наявність додаткових завдань, які можна рекомендувати студентам для самостійної роботи. Проте значна частина завдань повинна бути виконана всіма студентами.

Принцип зворотного зв'язку передбачає обов'язкову реакцію на дії студента при різних видах навчальної діяльності (наприклад, виправлення помилок, оголошення варіантів відповідей тощо)

Принцип інтерактивності є одним з провідних. Він полягає у взаємодії двох і більше сторін. Інтеракція відбувається за допомогою інформаційно-комунікаційних технологій i передбачає спілкування декількох комунікантів. Реальне спілкування здійснюється за допомогою форм телекомунікації (електронна пошта, чат, форум, Skype) і на платформах соціальних сервісів (блоги, вікі, подкасти та ін.).

Принцип свідомості відноситься до числа провідних дидактичних принципів, що реалізуються на заняттях. Реалізація даного принципу в навчанні означає свідоме ставлення студентів до самого процесу навчання, що передбачає оволодіння прийомами самостійної роботи.

Принцип активності передбачає мовну активність студентів у процесі навчання, що означає напруженість психічних процесів в діяльності учня, що стосуються уваги, мислення, пам'яті. Основними джерелами активності $є$ цілі, мотиви, бажання та інтереси. Для їх підтримки використовуються різні прийоми навчання, в тому числі завдання проблемного характеру, засоби наочності. Знання, вміння і навички формуються в процесі активної розумової роботи студентів [9].

Окреслені методичні принципи відображають різні аспекти навчального процесу і мають різні сфери застосування. Вибір форми навчання 


\section{ТЕХНОЛОГІЇ ВІЗУАЛІЗАЦІЇ В ПРОФЕСІЙНІЙПІДГОТОВЦІСПЕЦАЛІСТІВ}

студентів залежить від дидактичної мети, змісту навчального матеріалу, а також від рівня педагогічної культури викладача і стану навчально-методичної бази вузу. У свою чергу, форма організації навчання детермінує вибір дидактичних методів [10].

Розглянемо основні форми організації навчально-виховного процесу з використанням відеоматеріалів. Лекція методологічна й організаційна основа для всіх навчальних занять, зокрема й самостійних (методологічна, тому що вводить студента в науку загалом, надає навчальному курсу концептуальносгі; організаційна тому що решта форм навчальних занять так чи інакше “зав'язані” на лекцію, найчастіше логічно заплановані після неї, спираються на неї змістовно і тематично). Ї̈̈ основна дидактична мета формування орієнтованої теоретичної основи для подальшого засвоєння студентами навчального матеріал. Вона служить для пояснення важкої та складної теми; їі типовими ознаками, є введення та характеристика нових понять, розкриття та деталізація матеріалу, завершальні висновки викладача, відповіді на запитання (саме ці пункти i будуть нами використані у відеоматеріалах). Це теоретична форма навчання, основний метод усний, послідовний виклад змісту. Для лекції характерні великий обсяг навчального матеріалу, фундаментальність, складність логічних побудов, доказів і узагальнень. На ньому студенти отримують установку і напрямок для подальшої самостійної роботи [8].

На прикладі вивчення дисципліни “Комп”ютерна анімація” 3 нашого досвіду була обрана саме лекція 3 використанням відеоматеріалів, яка може бути як класичною так і проблемною. При класичній формі лекції відеоматеріали можуть використовуватись для активізації цілей, мотивів, бажання та інтересів студентів. При проведенні проблемної лекції за допомогою відеоматеріалів студенти запрошуються для роздумів і відповідей на проблемні питання. Методика проблемного викладу активізує студентів, сприяє розвитку аналітичного мислення.

Розкриємо практичний аспект нашого дослідження. Для створення відеоматеріалів сьогодні не обов'язково мати відеокамеру, досить скористатись безкоштовними комп'ютерними програмами, які можна знайти в Інтернеті. Процес їх створення складається 3 таких етапів: пошук, збір та підготовка матеріалів для створення відеоматеріалу; вибір програми; структурування відео [4].
На сьогоднішній день існує багато спеціальних засобів для запису відео $з$ екрану монітора. Конкуренція таких програм на ринку програмного забезпечення стимулює розробників до поліпшення і спрощення своїх продуктів. Тому використання програм такого типу не несе в собі ніяких складнощів і не вимагає від користувача особливих знань. Вибір засобів, які будуть використовуватися для створення відеоматеріалів залежить виключно від поняття зручності і можливостей комп'ютерної системи. Також важливою складовою вибору програмних засобів $\epsilon$ доцільність використання платних версій. Звичайно, програмні продукти, які розповсюджуються на безкоштовній основі, можуть мати деякі обмеження, такі, як: обмежений час запису відео, фіксований розмір файлу, не можливість зміни відео формату та інші. Але і серед безкоштовних програм можна знайти той варіант, який найбільше зможе задовольнити ваші потреби.

Для вивчення дисципліни “Комп'ютерна анімація" була обрана безкоштовна програма Synfig studio. У порівнянні з іншими програмними продуктами вона проста у використанні, але досить функціональна: створення і редагування анімацій в режимі реального часу (кисті, ефекти морфинга, інструменти графічного редактора тощо).

Метою дисципліни “Комп'ютерна анімація” $\epsilon$ навчити студентів створювати векторну 2D анімацію у вигляді відео заставок або цілих відео роликів на різну тематику, формувати мультиплікації з використанням безлічі функцій параметрів. Дисципліна складається з десяти тем відеоматеріалів, які демонструють етапи роботи в програмі Synfig studio і вже після першого перегляду дають можливість студентам швидко створювати векторну анімацію в реальному часі. Кожен відеоматеріал триває не більше п'ятнадцяти хвилин i супроводжуються текстовим матеріалом. Зміст відеоматеріалів наступний: 1. Способи анімації. Мета: розглянути основні способи анімації, ознайомитися з історією розрахунку і поняттями фази (проміжна, крайня, середня, ключова). 2. Створення фону. Мета: навчитися створювати персонажа різними способами (сканування, малювання та ін.), а також вміти їх редагувати. 3. Створення фону. Мета: навчитися створювати фонове зображення, згідно умов типографіки. Ознайомитися з теорією кольору. 4. Основи руху персонажа. Мета: навчитися способам планування ходьби, підскоки при ходьбі, анімація рухів верхніх і нижніх кінцівок. 5. Активні рухи персонажа. Мета: навчитися застосовувати схеми бігу, здобути навички ство- 


\section{ТЕХНОЛОГЇ ВІЗУАЛЗАЦЇ В ПРОФЕСІЙНІЙ ПДГОТОВЦІСЕЦАЛЛСТІВ}

рення анімації бігу, стрибків, стрибків в процесі бігу. 6. Міміка обличчя. Мета: навчитися створювати емоції на обличчі персонажа, додавати гнучкість в міміці. 7. Анімація зображення тварини. Мета: ознайомитися 3 рухами тварин. Навчитися використовувати базову модель ходьби тварини. 8. Анімація ефектів. Мета: навчитися створювати ефекти навколишнього середовища (вогонь, воду, вітер, дощ і ін.). 9. Робота зі звуком. Мета: навчитися озвучувати і синхронізувати зображення зі звуком. 10. Сценарій. Мета: навчитися стратегії розробки сюжету, монтажу і логічному завершенню проекту.

На сьогоднішній день існує багато спеціальних засобів для запису відео з екрану монітора. Конкуренція таких програм на ринку програмного забезпечення стимулює розробників до поліпшення і спрощення своїх продуктів. Тому використання програм такого типу не несе в собі ніяких складнощів і не вимагає від користувача особливих знань. Вибір засобів, які будуть використовуватися для створення відеоматеріалів залежить виключно від поняття зручності і можливостей комп' ютерної системи. Також важливою складовою вибору програмних засобів $\epsilon$ доцільність використання платних версій. Звичайно, програмні продукти, які розповсюджуються на безкоштовній основі, можуть мати деякі обмеження, такі, як: обмежений час запису відео, фіксований розмір файлу, не можливість зміни відео формату та інші. Але і серед безкоштовних програм можна знайти той варіант, який найбільше зможе задовольнити ваші потреби.

Розроблені відеоматеріали можна використовувати для демонстрації безпосередньо на аудиторних заняттях, для закріплення вивченого матеріалу та для самостійного вивчення програми Synfig studio.

Висновки 3 даного дослідження i перспективи подальших розвідок у даному напрямку. Таким чином, забезпечення якості професійної підготовки майбутніх інженерівпедагогів в сучасній вищій школі багато в чому обумовлено вибором сучасних освітніх технологій 3 використанням комп'ютерних технологій. Це актуалізує переорієнтацію традиційного навчання на принципово нове навчання, пов'язане з творчим розвитком особистості, зі зміною ролі студента, де він стає активним учасником освітнього процесу.

Розроблені відеоматеріали є базою для технології навчання комп'ютерній анімації у процесі професійної підготовки майбутніх інженерів-педагогів на прикладі дисципліни
“Комп'ютерна анімація” студентів Бердянського державного педагогічного університету (БДПУ), які сприяють підвищенню якості навчання і надають додатковий емоційний та інтелектуальний стимули для освіти.

В подальшому планується розробка відеоматеріалів до практичних занять, до типових завдань та завдань для самостійної роботи з дисципліни “Комп’ютерна анімація”.

\section{ЛIТЕРАТУРА}

1. Алєксєєва Г. М. Формування готовності майбутніх соціальних педагогів до застосування комп'ютерних технологій у професійній діяльності. Монографія. Бердянськ, 2014.

2. Алєксєєва Г. М., Бабич П. М. Використання платформи Arduino для професійної підготовки майбутніх інженерів-педагогів. Физикоматематическое образование. 2018, №. 4 (18). https: / /doi .org/10.31110/2413-1571-2018-018-4-002

3. Алєксєєва Г. М. Використання інформаційнокомунікаційних технологій в процесі професійної підготовки студентів педагогічних вузів. Актуальні питання природничо-математичної освіти. Суми, 2014. C.184-191.

4. Ашеров А. Т., Горбатюк Л. В. Организация самостоятельной работы будущих инженеров педагогов компьютерного профиля: состояние проблемы. Проблеми інженерно-педагогічної освіти. 2008. C. 84-93.

5. Глазунова О.Г. Методика навчання майбутніх фахівців аграрного профілю засобами комп'ютерної графіки. Київ, 2003.

6. Джеджула О.М. Теорія і методика графічної підготовки студентів інженерних спеціальностей вищих навчальних закладів. Тернопільський національний педагогічний університет імені Володимира Гнатюка, 2007.

7. Кравченко Л. М., Кравченко Н. В. Стратегії інженерно-педагогічної освіти в контексті інтеграції в європейський простір. Зб. наук. праць БДПУ (Педагогічні науки) №2. 2010. С. 113-118.

8. Нищак I. Д. Методична система навчання інженерно-графічних дисциплін майбутніх учителів технологій. 2017.

9. Нищак І.Д., Моштук В.В. Комп’ютерна графіка. Навч. посібник для вищих педагогічних навчальних закладів. Дрогобич, 2007.352 с.

10. Ожга М. М. Проблеми графічної підготовки майбугніх інженерів-педагогів унаукових дослідженнях. Проблеми інженерно-педагогічної освіти. 2012, №34-35. C. 226-233.

11. Fedorov A. Media educational practices in teacher training. 2015.

12. Kravchenko N.V., Alyeksyeyeva H.M., Gorbatyuk L.V. Curriculum Optimization by the Criteria of Maximizing Professional Value and the Connection Coefficient of Educational Elements, Using Software Tools: (ICTERI 2018: 14th International conference on ict in education, research, and industrial applications) [Електроний pecypc] 
(Kyiv, Ukraine, May 14-17, 2018). CEUR Workshop Proceedings, 2018, Vol.1, pp. 365-378.

13. Lavrik V., Cortez L., Alekseeva A., Garcна G. T., Juarez P. G., Poblano J. Development of the CAD system for designing non-standard constructions from elastomers. Development, 3(3), 2014.

14. Liu Z. Research on the Curriculum System Construction Plan for Animation Design and Production of Specialty in High Vocational Colleges. 2nd International Conference on Social Science and Technology Education (ICSSTE 2016). Atlantis Press, 2016.

15. Park S. Reviewing Educational Methodology in the Domain of Animation at the Smart Media Era. TECHART: Journal of Arts and Imaging Science. 2015, Vol. 2., No. 4., pp. 32-37.

\section{REFERENCES}

1. Alyeksyeyeva, H. M. (2014). Formuvannia hotovnosti maibutnikh sotsialnykh pedahohiv do zastosuvannia kompiuternykh tekhnolohii u profesiinii diialnosti [Formation of readiness of future social educators to use computer technologies in professional activity]. Berdyansk. [in Ukrainian].

2. Alyeksyeyeva, H. M. \& Babych, P. M. (2018). Vykorystannia platformy Arduino dlia profesiinoi pidhotovky maibutnikh inzheneriv-pedahohiv [Use the Arduino platform for the professional training of future engineer educators]. Physics and mathematical education, no (18). https://doi .org/10.31110/2413-15712018-018-4-002[in Ukrainian].

3. Alyeksyeyeva, H. M. (2014). Vykorystannia informatsiino-komunikatsiinykh tekhnolohii v protsesi profesiinoi pidhotovky studentiv pedahohichnykh vuziv [Victorious information-communal technologies in the process of professional training of students of pedagogical universities]. Topical issues of natural and mathematical education. Sumy, pp.184-91. [in Ukrainian].

4. Asherov, A. T. \& Gorbatyuk, L. V. (2008). Organizatsiya samostoyatelnoy raboty budushchikh inzhenerov pedagogov kompyuternogo profilya: sostoyanie problemy [Organization of independent work of future engineers of computer teachers: state of the problem]. Problems of engineering and pedagogical education, No.20, pp.84-93. [in Russian].

5. Glazunova, O.G. (2003). Metodyka navchannia maibutnikh fakhivtsiv ahrarnoho profiliu zasobamy kompiuternoi hrafiky [Methodology of training future specialists of agrarian profile by means of computer graphics]. Kyiv. [in Ukrainian].

6. Dzhedzhula, O.M. (2007). Teoriia i metodyka hrafichnoi pidhotovky studentiv inzhenernykh spetsialnostei vyshchykh navchalnykh zakladiv [Theory and methodology graphically ï preparation of students of engineering specialties of different schools]. Ternopil National Pedagogical University named after Volodymyr Hnatyuk [in Ukrainian].

7. Kravchenko, L. M. \& Kravchenko N. V. (2010). Stratehii inzhenerno-pedahohichnoi osvity v konteksti intehratsii v yevropeiskyi prostir [Strategies of engineering and pedagogical education in the context of integration into the European space]. Collection of scientific works of the Berdyansk State Pedagogical University (Pedagogical Sciences), no.2, pp.113-118. [in Ukrainian].

8. Nyshchak, I. D. (2017). Metodychna systema navchannia inzhenerno-hrafichnykh dystsyplin maibutnikh uchyteliv tekhnolohii [Methodology of training future specialists of agrarian profile by means of computer graphics]. [in Ukrainian].

9. Nyshchak, I.D. \& Moshtuk, V.V. (2007). Kompiuterna hrafika [Computer Graphics]. A manual for higher pedagogical educational institutions. Drohobych, 352 p. [in Ukrainian].

10. Ozhha, M. M. (2012). Problemy hrafichnoi pidhotovky maibutnikh inzheneriv-pedahohiv u naukovykh doslidzhenniakh [Problems of graphic training of future engineers-teachers in scientific researches]. Problems of engineering and pedagogical education. No. 34-35, pp. 226-233. [in Ukrainian].

11. Fedorov, A. (2015). Media educational practices in teacher training. [in English].

12. Kravchenko, N.V., Alyeksyeyeva, H.M. \& Gorbatyuk, L.V. (2018). Curriculum Optimization by the Criteria of Maximizing Professional Value and the Connection Coefficient of Educational Elements, Using Software Tools: (ICTERI 2018: 14th International conference on ict in education, research, and industrial applications). Kyiv, Ukraine, May 14-17, 2018. CEUR Workshop Proceedings, no.1, pp. 365-378. [in English].

13. Lavrik, V. Cortez, L. Alekseeva, A. Garcна, G. T. Juarez, P. G. Poblano, J. (2014). Development of the CAD system for designing non-standard constructions from elastomers. Development, no. 3(3), pp. 80-91. [in English].

14. Liu, Z. (2016). Research on the Curriculum System Construction Plan for Animation Design and Production of Specialty in High Vocational Colleges. 2nd International Conference on Social Science and Technology Education (ICSSTE 2016). Atlantis Press. [in English].

15. Park, S. (2015). Reviewing Educational Methodology in the Domain of Animation at the Smart Media Era. TECHART: Journal of Arts and Imaging Science, no. 2(4), pp. 32-37. [in English].

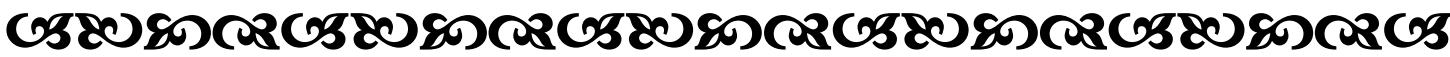

“Не важливо, наскільки повільно ти рухаєшся вперед доти, поки ти не зупиняєшся". Конбууиiü

давньокитайсъкий білособб

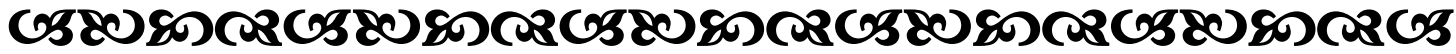

